\title{
Innovation and new product development: Key to building shareholder value in forest products
}

\author{
by Patricia M. Mohr ${ }^{1}$
}

\section{Introduction}

Canada's forest products industry has long been a commodityoriented sector based on large volume exports of competitively priced products to the United States and overseas markets. Research and development (R\&D) expenditures have been relatively low, especially in the area of "new product development," though Canada has long been a leader in "process technology" for newsprint and groundwood specialty papers. In recent years, corporate $\mathrm{R} \& \mathrm{D}$ spending has waned furtherpossibly to critically low levels-under the weight of intensified cost cutting.

International comparisons of R\&D expenditures are difficult to make. However, it is noteworthy that the Finnish paper industry increased its spending on R\&D by $33 \%$ in 2000 , while the wood products sector almost trebled its spending. The Finnish forest products cluster (including equipment manufacturers and chemical producers) spent a total of US\$462 million (euros 500 million) on R\&D last year. In Canada, R\&D spending totalled US\$232 million in 1999 (C\$345 million) (Watts and Kozak 2000), though these estimates are not directly comparable, because they exclude spending by supplier industries. A number of major Finnish paper companies spend well under $1 \%$ of their revenue on $R \& D$ (about $0.5-0.8 \%$ - not an impressive figure- though Finnish suppliers such as papermaking equipment manufacturers often dedicate a relatively high $3-4 \%$ of revenue to research. A close relationship with world-class equipment and chemical producers has probably contributed to the technical advantage of Finnish coated papermakers.

In its October 2001 Global Competitiveness Report, the World Economic Forum declared Finland to be the most competitive of the 75 countries examined, with the best prospects for economic growth over the next five years (Reference). Finland's number one ranking is largely based on its emphasis on technology and a corporate and national culture which nurtures innovation. Superior technology in coated papers has enabled Finnish companies to expand their market share and corporate ownership across Europe and the United States.

Today, a strong case can be made for a renewed commitment to R\&D in Canada both in "process technology"- - key to boosting productivity and maintaining a competitive edge in commodity-grade products — as well as a greater emphasis on innovative, value-added products. This is particularly so in view of the industry's generally inadequate return on shareholders' equity in the 1990s and the need to attract and retain institutional investor capital.

${ }^{1}$ Vice-President, Economics, Industry and Commodity Markets Research, The Scotiabank Group, Toronto. E-mail: pat_mohr@scotiacapital.com. Ms Mohr is a member of Canada's National Advisory Board on Forest Research (NABFOR), appointed by the Minister of Natural Resources Canada.

\section{Inadequate Share- holder Returns in the 1990s}

During the 1990s, a sample of Canadian publicly traded forest products companies (in pulp, paper and wood products) posted a return on shareholders' equity of only $0.7 \%$ considerably lower than the $9.2 \%$ average of the 1980 s or the $13 \%$ average of $1985-89$ (using a Scotia Economics

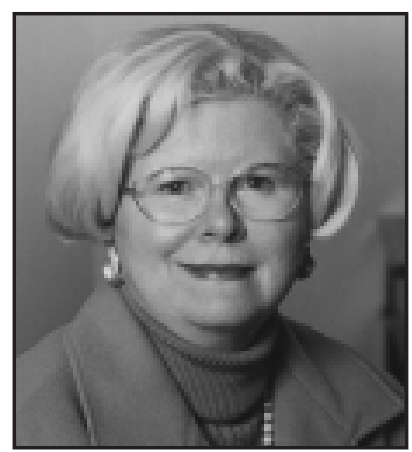

Patricia M. Mohr sample). Returns were only modestly better in the United States, averaging $6.9 \%$ from 1990-99, boosted by stellar $20 \%$ results at several R\&Dintensive consumer tissue manufacturers. There were many years when the industry on both sides of the border did not cover its cost of capital.

The slower pace of global growth during the 1990sencompassing a sharp international recession in the early 1990s, a mid-decade slowdown in the United States and the Asian currency crisis of 1997-98-was generally not conducive to strong commodity prices. The net result was that institutional investor interest in Canadian and U.S. forest products companies waned dramatically in the late 1990s, triggering today's greater corporate awareness of the need to bolster shareholder returns.

\section{Creating Greater Shareholder Value}

So far, the steps taken to boost shareholder value (that is, share price appreciation and dividends) in Canada and the United States have largely involved the following:

1) industry consolidation through mergers and closure or modernization of outdated mills to reduce costs, lessen industry fragmentation and stabilize prices through tighter inventory management during weak market conditions;

2) re-assessing global competitive strengths, re-focussing on "core competencies" and divesting assets outside the core or that do not meet target rates of return; and

3) a slower, more disciplined approach to capacity expansion, rather than chasing new project developments and market share as in the 1980s and early 1990s. Over-investment in new facilities was probably one of the key factors reducing returns in the 1990s. More emphasis on new product development, specialized customer service and marketing programs - rather than mill expansion-may yield bigger dividends for shareholders.

4) In Canada, some shift away from standard-grade newsprint to higher value-added supercalendered paper and other groundwood specialty grades.

These steps are beginning to pay off and, together with strong economic growth in 2000, contributed to last year's improved return on shareholders' equity of $11.5 \%$ in Canada and $10.4 \%$ 
in the United States. However, a fourth measure-a renewed commitment to new process development and greater emphasis on innovative products through R\&D—would also boost shareholder returns.

The appropriate level of R\&D spending for a particular company will depend partly upon its competitive strategy, which can be classified in three ways: cost minimizing (commodity producers), sales maximizing (for example, consumer products manufacturers who boost revenue on thin margins through promotion, advertising and tight inventory management) and performance maximizing (high-tech manufacturers competing on the basis of knowledge and a constant flow of new products) (Binkley and Forgacs 1997). While commodity producers will necessarily spend less on $\mathrm{R} \& \mathrm{D}$, cutting costs through leading edge "information" and "process" technology may be key to maintaining a competitive edge. Competition from new, low-cost plantation producers in Latin America and the Far East has intensified in the past decade and changes in market requirements in the Far East will require new product development.

\section{R\&D is a Way of "Growing" Demand}

Finally, a business plan that makes R\&D and new product development a strategic priority (at least for part of the operation) has the following advantages:
1) R\&D is a way of "growing" and creating new demand rather than accepting "maturing" markets-important because of the increasing maturity of many forest products markets in North America;

2) The price premium for "specialty" products is maintained and in some cases widens during economic setbacks. This is the case for melamine overlaid particleboard or MDF and specialized packaging products; and

3) Value-added products are less likely to attract trade restraints by competitors, in contrast to commoditygrade products.

In many ways, innovation is the key to tomorrow.

\section{References}

Watts, S. and R. Kozak. 2000. Status of Forestry Related Research in Canada, 1999/2000, A report prepared for FORCAST. Faculty of Forestry, University of British Columbia, Vancouver, BC.

Binkley, C. S. and O.L. Forgacs. 1997. Status of forest research and development in Canada. FORCAST report. http://forcast.forest. ca/pdf/binkrp_e.pdf 